\title{
O PRimeiro Modernismo nos Ensaios DE ANTONIO CANDIDO
}

\section{The first Modernism in the essays of Antonio Candido}

\author{
Irenísia Torres de Oliveira*
}

\section{INTRODUÇÃO}

Para discutir o pensamento de Antonio Candido sobre o Modernismo, e mais especificamente, o primeiro Modernismo, é necessário considerar que o próprio crítico se via, como intelectual, com um papel no processo de renovação da mentalidade intelectual empreendida pelo movimento. Num depoimento dado a Mario Neme, em 1943, o jovem crítico, então com vinte e cinco anos, justificava a tendência de sua geração para o estudo e a análise como uma exigência do momento histórico, inserida no mesmo processo de renovação que o dos modernistas.

Nesse depoimento, procura tomar posição diante das gerações anteriores e responder à má vontade que cercava os intelectuais de seu tempo por serem exclusivamente críticos, analistas rigorosos, e não artistas. Responde à provocação de Oswald, publicada na revista Clima ("A sua geração lê desde os três anos. Aos vinte tem Spengler no intestino. E perde cada coisa!"), justificando a própria atitude com a força de uma tarefa histórica que se apresenta.

É preciso compreender que o surto dessa tendência para o estudo corresponde em nós a uma imposição da necessidade social de crítica. É a necessidade de pensar as coisas e as obras, inclusive as que você e os seus companheiros fizeram, sem compreender bem o que estavam fazendo, como é de praxe (CANDIDO, 2002a, p. 241). 
Pode-se perceber um sentido de responsabilidade, como se os intelectuais da nova geração paulista se sentissem cobrados a manter o nível de intervenção das gerações de 20 e 30 . Há um entendimento de continuidade do processo, no qual agora os mais jovens entram com a tarefa de analisar, compreender e sistematizar.

Antonio Candido não publicou longos estudos para sistematizar o movimento modernista, nada do porte da Formação da Literatura Brasileira, mas podemos encontrar avaliações e propostas de articulações bem variadas em alguns ensaios, de visada panorâmica. Nos anos 50, publicou dois textos que mais tarde seriam refundidos no ensaio Literatura e cultura de 1900 a 1945, publicado no livro Literatura e sociedade (2000/1965). O texto se apresenta no subtítulo justamente como "panorama para estrangeiros" e se articula em torno das preocupações de Antonio Candido no período, relativas ao sistema literário. Tanto que o panorama se inicia com a seguinte frase: "Se fosse possível estabelecer uma lei de evolução da nossa vida espiritual, poderíamos talvez dizer que toda ela se rege pela dialética do localismo e do cosmopolitismo, manifestada pelos modos mais diversos" (CANDIDO, 2000, p. 109). A primeira frase do livro Formação, escrito no mesmo período, indica também o programa de estudos regido por aquela suposição: "Este livro procura estudar a formação da literatura brasileira como síntese de tendências universalistas e particularistas" (CANDIDO, 1993, p. 23).

No panorama dos anos 50 , já articula os dois pontos importantes das sistematizações que propôs para o movimento: a ruptura do primeiro Modernismo com o período anterior e sua continuidade com o de 30. Percebese, portanto, a preocupação de estabelecer uma série de rupturas e continuidades, além de conflitos do campo literário e ideológico, configurando fragilidades e desdobramentos do sistema literário.

No texto da Plataforma da nova geração, do início dos anos 40, há uma tendência do crítico de separar-se da geração de 20 (um estouro de enfants-terribles) e aproximar-se da de 30 . Embora admitisse que ele e seus contemporâneos seriam continuadores naturais daquela geração, porque teriam herdado os problemas que ela não conseguira resolver, reconhecia na última uma espécie de filiação: "Nós nos formamos sob o seu influxo e somos em grande parte o seu resultado. A nossa orientação intelectual se delineia na atmosfera de suas lutas políticas, dos seus partidos extremos dos quais vamos aprender muita coisa [...]" (CANDIDO, 2002a, p. 240). Nesse momento, por mais respeito que demonstre pelos intelectuais de 20 , a grande admiração recai nos artistas e intelectuais de 30 "Para falar a verdade, com os de 30 é que começa a literatura brasileira" (CANDIDO, 2002a, p. 239). 
Entretanto, nos panoramas sobre literatura e cultura publicados a partir dos anos 60, mistura-se à ênfase dada à década de 30 como amadurecimento e culminância, a importância crescente conferida ao primeiro Modernismo, como semeador, catalisador e organizador da renovação consolidada na década seguinte. Efetivamente, Antonio Candido apresenta o primeiro Modernismo como aquele que coordenou e providenciou a ruptura, embora de maneira restrita e excepcional, e forneceu as sementes para os frutos amadurecidos de 30 . Em 20, a renovação estava dada em potência; em 30, era concretizada, realizando os grandes objetivos da primeira fase: enfraquecimento do academicismo, direito à inovação formal e temática, reconhecimento da literatura regional em escala nacional. Embora o momento seguinte fosse fundamental, porque sedimentava e dava razão à agitação anterior, os valores e critérios, ou seja, o caminho a seguir, já estava dado no momento anterior.

Podemos talvez até dizer que, se na Formação da Literatura Brasileira o ponto de vista adotado era o dos românticos, como elemento explicativo ou metodológico declarado, embora o autor muitas vezes discordasse de seus critérios, o ponto de vista assumido nos ensaios ou comentários mais gerais sobre o Modernismo é, salvo engano, já que não explicitado pelo autor, o dos primeiros modernistas. Os valores e pontos de vista críticos praticados parecem estar mais ligados ao primeiro Modernismo que à geração posterior.

\section{O PRIMEIRO MODERNISMO No SISTEMA LITERÁRIO}

O Modernismo é pensado no ensaio Literatura e cultura de 1900 a 1945, sobretudo a partir da dialética entre local e universal. Ao lado do Romantismo, constituía um dos "momentos decisivos" na literatura brasileira, de mudança de rumos e revigoração do pensamento em geral, possuindo ambos em comum o fato de priorizarem o local, embora apoiados nos modelos europeus. A diferença residia em que o particularismo romântico se afirmava por uma rejeição da herança portuguesa, que no Modernismo já estaria superada e esquecida, afirmando-se este em combate contra o academismo cosmopolita.

Assim, o Modernismo inaugurava um novo momento na dialética de local e universal, afirmando o primeiro dos termos pelo recurso ao segundo, ou seja, afirmando-se o dado local pela valorização vanguardista (europeia) do primitivo. Promovia, então, a aceitação dos componentes recalcados da nacionalidade, principalmente ligados à nossa condição de país etnicamente mestiço e culturalmente influenciado por culturas 
primitivas, ameríndias e africanas. "As nossas deficiências, supostas ou reais, são reinterpretadas como superioridades. [...] O primitivismo é agora fonte de beleza e não mais empecilho à elaboração da cultura" (CANDIDO, 2000, p. 120).

Além da nova atitude de valorização do elemento primitivo, a expressão literária do desrecalque localista tinha sido buscada também nas vanguardas, principalmente francesa e italiana. Mas esse empréstimo agora assumia um caráter diferente, por dois motivos: primeiro, porque não estávamos mais tão distantes material e culturalmente da Europa e também éramos atingidos pelos efeitos da velocidade e da mecanização, das agitações sociais e ideológicas que tinham constituído os estímulos das vanguardas; segundo, porque os processos artísticos radicais dos vanguardistas europeus terminavam tendo maior coerência e possibilidade de assimilação num ambiente como o nosso, em que se convivia cotidianamente com as culturas primitivas. A conclusão do autor é de que, do ponto de vista da dialética de local e universal, nos anos 20 e 30, empreendeu-se um "admirável esforço de construir uma literatura universalmente válida por meio de uma intransigente fidelidade ao local" (CANDIDO, 2000, p. 126). O Modernismo mostrava-se, portanto, como um importante momento de síntese na dinâmica literária brasileira.

O equacionamento das tendências localistas e universalizantes indicava também um outro aspecto de grande interesse para o crítico, que era o estabelecimento de uma tradição literária local. Mais de uma década depois de formuladas as ideias sobre a adequação dos recursos vanguardistas europeus às necessidades expressivas locais, o autor vai chamar a atenção para as conquistas modernistas relacionadas à continuidade literária, em artigo publicado numa revista portuguesa. "A partir de 1922, encontramos cada vez mais escritores que não apenas filtram com originalidade as influências externas, mas se formam, nas coisas essenciais, a partir de antecessores brasileiros" (CANDIDO, 2002b, p. 118).

Para mostrar os avanços nesse sentido, dá os exemplos de Mário de Andrade e Manuel Bandeira, cujas obras seriam impossíveis de compreender sem recorrer a fontes externas. No caso do primeiro, seriam os unanimistas franceses, futuristas italianos, as teorias estéticas franceses, como de Paul Dermée, e, no do segundo, Cesário Verde, Antonio Nobre, os simbolistas belgas. Este já não seria o caso, por exemplo, de Drummond, João Cabral ou Guimarães Rosa, cujas influências preponderantes podiam ser encontradas nos antecessores brasileiros e as fontes externas, quando existiam, apareciam subordinadas ou combinadas a uma tradição literária capaz de apoiar e nortear a produção de obras de valor. 
Pensando nos desdobramentos do sistema literário, como Antonio Candido configurou na Formação da Literatura Brasileira, sentimos falta de uma articulação entre o momento alto do surgimento da obra de Machado de Assis, que mostra a formação do sistema, e o Modernismo. Na prosa, com Machado, já se constituíra uma continuidade, o que não aconteceria na poesia, ainda muito voltada para modelos externos.

Os exemplos dados por Candido nesse artigo, perseguindo a ideia de modernidade e de continuidade, são, na sua grande maioria, de poetas. É como se a renovação modernista, no caso da poesia, pudesse ser explicada de maneira convincente nos limites do movimento, o período considerado por Antonio Candido em suas avaliações, 1922-1945. No caso da prosa, parece ser mais difícil a visão localizada da renovação. $O$ único exemplo de narrativa, na perspectiva da continuidade, é o de Guimarães Rosa, mostrando como poderíamos, talvez, supor uma fonte em Joyce, sem que ela, se realmente houve, aparecesse de maneira diretamente reconhecível.

A ideia de continuidade na prosa parece exigir uma consideração mais ampla no tempo, uma diferenciação menos nítida em termos de tradição e modernidade, porque as fontes muitas vezes, no caso brasileiro, remetem a obras anteriores ao advento das vanguardas. Os exemplos dados por Candido para a poesia citam fontes já vanguardistas, mas talvez não fosse possível o mesmo para a prosa, que possui uma trajetória anterior e segue outro caminho. Enfim, a conquista da narrativa moderna parece ser mais difícil de restringir ao período modernista, no Brasil e na Europa, demarcando rupturas claras. Graciliano Ramos, nosso maior romancista de 30, deve mais a Dostoiévski e a Machado do que aos narradores de Vanguarda. Se aproxima-se de Kafka e dos expressionistas, em alguns momentos, é mais justo pensar que essa proximidade se deva a terem recorrido a fontes comuns para empreenderem uma renovação sentida como necessária, em um tempo em que os conflitos se mundializavam por causa das guerras. Talvez por isso, com as ressalvas que se lhe possa fazer, Graciliano pareça mais maduro que os escritores de 20.

Nesse sentido, e se não estou enganada, a proposta de sistema literário de Antonio Candido interfere na tentativa de detectar os avanços modernistas, principalmente na prosa. Se, com Machado de Assis, como se propõe na Formação, o sistema já está formado, porque se mostra capaz de dar massa crítica para o trabalho do grande escritor, a tentativa de explicar a renovação da narrativa como ruptura localizada dentro dos limites modernistas pode deixar de contemplar alguns elos fundamentais para a compreensão do processo instaurado pelo próprio sistema literário em funcionamento. 


\section{A RENOVAÇÃo: GRANDES VERTENTES}

Em grandes linhas, a renovação empreendida pelo Modernismo é apresentada por Antonio Candido como a libertação de antigas restrições, articulada em duas vertentes: em termos temáticos ou ideológicos, a expansão propiciada pelo que chamou de desrecalque localista, e, em termos propriamente estéticos, a pesquisa formal dirigida para as técnicas vanguardistas europeias. Tal configuração artística permitia que, ao mesmo tempo, nossa vida intelectual pudesse estar atualizada com o mundo e incluir aqueles elementos que antes deviam ser recalcados, a bem dessa atualização. A direção apontada pela vanguarda europeia foi então uma alternativa para o problema do complexo de inferioridade que nossos intelectuais nutriam em relação à Europa, traduzido ora em rejeição xenófoba, ora em cópia servil. Isso porque, segundo Antonio Candido, as combinações de progresso tecnológico e primitivismo experimentadas pelas vanguardas eram muito mais adequadas a nossa experiência histórica que à europeia.

\subsection{Desrecaloue Localista}

Tudo aquilo que, antes, envergonhava, porque marcava nossa distância em relação à Europa, as presenças do negro e do índio em nossa formação étnica, a mestiçagem, as culturas consideradas primitivas, agora podia ser trazido à tona com orgulho, até com euforia, e transformados em superioridade. Macunaíma seria a síntese do desrecalque empreendido pelos primeiros modernistas:

Mário de Andrade, em Macunaíma (a obra central e mais característica do movimento), compendiou alegremente lendas de índios, ditados populares, obscenidades, estereótipos desenvolvidos na sátira popular, atitudes em face do europeu, mostrando como a cada valor aceito na tradição acadêmica e oficial correspondia, na tradição popular, um valor recalcado que precisava adquirir estado de literatura (CANDIDO, 2000, p. 120).

A valorização desse aspecto por Antonio Candido está relacionada com a situação intelectual do período, um momento em que já se reconhece o caráter miscigenado de nossa formação étnica e cultural, mas também se experimenta um grande complexo de inferioridade por causa disso. As teorias raciais, ainda em voga no período, apontam para a inferioridade das raças não brancas e mestiças, num grande debate naturalista, em que o homem é tratado no mesmo patamar, e com os mesmos termos, de qualquer espécie 
animal. A perspectiva de sair da raça para a cultura, a aceitação e mesmo a exaltação da cultura desses contingentes discriminados representam um avanço possível. Macunaíma, já a partir do subtítulo, entra na discussão muito viva naquele tempo sobre o caráter nacional brasileiro, geralmente pontuada por lamentações de todo tipo, um certo consenso de elite de que o povo brasileiro não prestava e era seu álibi para deixá-lo à míngua de educação e outros melhoramentos civilizacionais. A exaltação do elemento popular, ainda que constituindo uma espécie de exotismo interno, tinha o seu lado libertário e de confronto com a mentalidade atrasada de grande parte das camadas dominantes.

Antonio Candido faz uma diferenciação, no que tange à valorização do país, entre as tendências que pretendiam "exprimir a essência" do país e os que desejavam pesquisá-lo. Nos primeiros, estava o pessoal do verdeamarelismo e da Anta, nacionalistas conservadores, cuja visão estética se desdobraria numa visão política fascista; entre os últimos, preocupados com a pesquisa, estavam Oswald, Mário de Andrade e Raul Bopp, nos quais o crítico reconhecia "mais humour, maior ousadia formal, elaboração mais autêntica do folclore e dos dados etnográficos, irreverência mais conseqüente, produzindo uma crítica bem mais profunda" (CANDIDO, 2000, p. 122).

Posto na cena entre o tradicionalismo passado e o conservadorismo contemporâneo, o primeiro Modernismo realmente se apresentava como uma alternativa importante, não apenas em termos estéticos, mas também críticos.

Apesar disso, e com o passar do tempo, foi-se tornando mais visível que a intenção militante de tratar nossas deficiências como superioridades tinha um limite crítico. Roberto Schwarz trata do problema em dois estudos: primeiro, no ensaio A carroça, o bonde e o poeta modernista (1987), sobre a poesia Pau-Brasil de Oswald de Andrade, e segundo, no livro Duas meninas (1997), já nas conclusões, quando trata mais especificamente da obra de Mário de Andrade.

No caso de Oswald, o desrecalque significava alçar os nossos atrasos e sobrevivências pré-burguesas ao mesmo patamar das conquistas do progresso tecnológico e das instituições burguesas, que importávamos. Tal convivência, no Brasil, poderia estar formando uma combinação nova, capaz de redimir o cansaço da sociedade liberal burguesa europeia. Por isso, na poesia Pau-Brasil encontram-se ao mesmo tempo a euforia pelo progresso, visto como inocente, e pelos elementos pré-burgueses de nossa formação.

Para Schwarz, tanto nos diários de Helena Morley, quanto na poesia Pau-Brasil de Oswald e na obra de Mário, a visão simpática da sociedade brasileira necessita da supressão (do recalque?) de aspectos incômodos da realidade. Nos diários da menina, a exclusão de tais aspectos se deveu ao 
próprio momento histórico, um momento de repouso na marcha do progresso, que permitiu certa liberdade de tocar a vida fora de seus esquadros.

No caso dos autores modernistas, essa visão é altamente construída, a partir de instrumentos artísticos poderosos, que dão conta da diversidade de elementos em jogo, e se propõem como artefatos modernos. Diferentemente de Helena, ambos vivem em um momento de forte intervenção do progresso econômico, catalisado pela lavoura do café. o desafio ao qual os dois se lançam, na visão de Schwarz, é encontrar a forma de convivência entre as esferas do progresso, capitaneado pelas elites paulistas, e os traços pré-burgueses de nossa formação, em que constam a informalidade, o familismo etc. No caso específico de Mário, a intenção edificante de aperfeiçoar a nacionalidade encontra-se combinada a cada passo com o timbre transgressor. Nesse ponto, o crítico lembra que Machado de Assis também tentara, nos romances da primeira fase, estabelecer uma possibilidade de convivência decente entre as famílias abastadas e seus dependentes, mas só alcançou verdadeira estatura crítica quando desistiu das formas conciliatórias e passou a figurar os impasses da desigualdade nas relações sociais do país (SCHWARZ, 1997, p. 141-3).

Está embutido aí um programa de modernizar a visão das elites e chamá-las à responsabilidade pelo país. Nisso Mário não está sozinho no começo do século XX. O momento é de percepção por grande parte dos intelectuais de que o projeto nacional está ameaçado, externamente pelas tendências imperialistas do período, e internamente pela fragilidade do tecido social. Fazem-se críticas à elite brasileira pela falta de liderança na constituição de uma nação forte, internamente coesa, e chama-se a mesma elite para assumir o compromisso de conduzir e reformar o país, o que inclui aceitar o povo mestiço e sem instrução como seu povo e sua responsabilidade. Esta forma de ver se encontra em autores ideologicamente antagônicos como Manuel Bomfim e Alberto Torres.

Nesse sentido, a literatura de Mário e de Oswald tem um sentido de engajamento, quando procura mostrar o povo brasileiro ao mesmo tempo simpático e adaptável ao progresso, de maneira que o avanço econômico e tecnológico não precise significar um atentado à nacionalidade, um fator de divisão, mas um elemento capaz de funcionar e ser melhorado, em relação à Europa, pelos traços pré-burgueses de nossa formação ${ }^{1}$. Em termos críticos, o momento de verdade da obra dos dois modernistas, o que as faz inflectir diferente e as impede de figurarem como justificação ideológica, é o humor.

${ }^{1}$ Tenho tentado mostrar como a obra de Lima Barreto trabalha na percepção do impasse entre as sobrevivências desagregadoras da sociedade colonial proprietária e as novas tendências desagregadoras da sociedade de consumo. Em nenhuma das duas formas, o autor carioca vê as sementes de uma sociedade mais coesa. Por isso, provavelmente, a nacionalidade, grande obsessão do período, aparece como projeto frustrado no romance de Policarpo. 
Antonio Candido e Roberto Schwarz vinculam as avaliações positivas da obra de Oswald de Andrade à consideração do sarcasmo. Para o primeiro, porque é uma solução estética e crítica, como veremos mais adiante, e, para o segundo, porque relativiza a ideologia do progresso inocente. A aspiração ideológica recebe um viés crítico pelo "ar de piada" que envolve "a decisão de colocar no 'presente do universo' - e com sinal energicamente positivo! - o nosso provincianismo e as nossas relações rurais atrozes" (SCHWARZ, 1987, p. 28).

São limites críticos importantes, que entram obrigatoriamente na discussão atual do pensamento sobre o Brasil, mas do ponto de vista daquele período e dos grupos que empreenderam o movimento modernista, representam de fato uma ruptura e uma consciência crítica mais avançada, como Antonio Candido procurou mostrar, muito atento aos debates do início do século XX.

\subsection{CONQUISTAS FORMAIS}

A renovação formal no primeiro Modernismo também é pensada em termos de ruptura com os ideais estéticos do período anterior a 1922, dominado pelo convencionalismo e a superficialidade. Quais seriam propriamente as conquistas formais do movimento?

Nos panoramas, Antonio Candido enfatiza mais atitudes que recursos propriamente. A grande conquista é o direito à pesquisa e à liberdade de criar, o grande legado deixado por 20 para 30. Mais especificamente, aponta como conquistas a incorporação da linguagem coloquial à linguagem literária, as experimentações que rompem os limites entre prosa e poesia, sobretudo em Oswald, a desarticulação da narrativa tradicional pela descontinuidade e a simultaneidade (mais uma vez Oswald), teorizadas por Mário de Andrade n'A escrava que não é Isaura.

Nas análises sobre a obra de Oswald, pode-se perceber bem a maneira como Antonio Candido encarou a questão da forma. Na análise que fez dos seus romances, ainda nos anos 40, aponta as permanências de esteticismo e a busca de rompimento com o passado. 0 artigo chama-se justamente Estouro e libertação. O grande problema detectado nesse momento é que a liberdade oswaldiana só se apresenta como rejeição completa, como momento negativo, de sátira, sarcasmo e pilhéria, da maneira que surge no par Miramar-Serafim. O crítico elogia as "soldas arrojadas", a "concisão lapidar", por meio das quais "Oswald de Andrade consegue quase operar uma fusão da prosa com a poesia" (CANDIDO, 1992b, p. 26). Mas mantém a expectativa de que a obra chegasse a uma síntese, pela superação do 
momento ainda tradicionalista e do momento puramente negativo de sátira social. Referindo-se ao primeiro romance da série Marco Zero, A revolução melancólica, diz que "ultrapassou o esteticismo desvairado da fase católicoparnasiana assim como a crítica puramente negativa do período seguinte (porventura melhor, literariamente falando), lançando-se numa perspectiva sintética de crítica social construtiva" (CANDIDO, 1992b, p. 32).

Mais tarde, em artigo de 1970, faz uma série de ressalvas a essa primeira avaliação da obra de Oswald. Mesmo julgando ter acertado em muitas análises e julgamentos, considera ter sido um erro pensar que o melhor do escritor ainda estivesse por vir. Esta expectativa havia sido disseminada pelo próprio Oswald. Na época, o autor gostava de dar a entender que sua obra definitiva ainda estava para ser escrita. Candido reconhece, na análise de 1970, que a obra definitiva de Oswald era o par Miramar-Serafim e muda de opinião em relação ao valor dos dois livros. Nos anos 40, considera o Miramar um ponto de equilíbrio e classifica o Serafim como "fragmento de grande livro". Depois, a avaliação se inverte. $O$ Serafim será visto como uma obra mais radical e mais sofisticada que o Miramar, constituindo o ponto máximo do impulso renovador oswaldiano (CANDIDO, 2004, p. 57-8).

A série Marco Zero é avaliada não como superação da obra anterior, mas como o momento de mais uma tentativa de escrever romance sério, como havia sido a Trilogia do exílio. Nas obras de Marco Zero, impôs-se mais um elemento passadista da formação do escritor. "[...] Oswald conservou de maneira recessiva um veio naturalista que estufou no decênio de 1930, estimulado pela moda de literatura documentária e social dominante" (CANDIDO, 2004, p. 53-4).

No entanto, o fracasso da série serviu para uma avaliação mais minuciosa dos pontos fortes da literatura oswaldiana. Antonio Candido mostra que o ponto de inflexão não estava no uso das técnicas vanguardistas (simultaneísmo, pontilhismo, descontinuidade), que se encontravam também nos livros "sérios", mas na combinação altamente feliz que essas técnicas alcançavam com a atitude que chamou de sarcasmo-poesia. A mesma potencialização não acontecia nos romances da Trilogia nem de Marco Zero. Pelo contrário, nestes as técnicas mesmas se desvigoravam pela direção dominante do esteticismo ou do naturalismo (CANDIDO, 2004, p. 53).

Nos ensaios sobre a obra de Oswald, as questões de forma são preponderantes, procurando desvendar as relações entre o uso de técnicas vanguardistas e a felicidade da composição narrativa. A diferença entre o ensaio de 1945 e o de 1970, que revisa o primeiro, é a mudança de consideração da unidade narrativa, seguindo o princípio aristotélico, que o levara inicialmente a valorizar o Miramar acima do Serafim. A aceitação da 
sátira como realização definitiva que inscreve o nome do escritor na história da literatura brasileira também representa uma superação dos valores clássicos. Em 1970, Antonio Candido já não vê mais na técnica sincopada do Serafim "certa preguiça de aprofundar os problemas de composição", mas o grande trunfo do autor, a forma de expressão que lhe permitira a melhor realização literária.

É possível perceber a virada crítica para uma forma de avaliação mais adequada à literatura que se fazia no século XX, mas também muito voltada para questões "especificamente" literárias. Isto segue naturalmente a visão de Antonio Candido de que a elaboração formal da estrutura e do estilo é a "chave do acerto em arte e literatura" (CANDIDO, 1989b, p. 197).

Nestes ensaios, sentimos falta da consideração dos fatores sociais envolvidos também como fatores estéticos, restringindo-se estes normalmente a elementos técnicos e de composição narrativa, o que talvez se justifique porque aí se busque uma visão geral da obra e menos uma análise mais apurada dos fatores. No mesmo ano, 1970, o crítico publicaria o conhecido ensaio Dialética da malandragem, que empreende uma análise norteada por reflexões acerca da relação entre matéria narrativa e valor estético.

A justificativa para o formalismo estrito das análises talvez se encontre na própria configuração da obra de Oswald e na ênfase que deu à experimentação formal, indicando ao crítico a necessidade de se entender os êxitos e fracassos dos experimentos, a significação deles no conjunto de sua obra. Além disso, a compreensão e sistematização das pesquisas formais reforçavam, de maneira mais geral, o embate modernista contra os convencionalismos da época, quer dizer, mostravam a amplitude e a consistência dos novos recursos formais, esclarecendo, para não passarem despercebidas, as conquistas estéticas. Estas significavam, afinal, não apenas superações individuais, mas também o legado do movimento.

Em estudo posterior, de 1970, o âmbito de avaliação não muda. Quando Candido descobre a relevância da afinidade entre as técnicas vanguardistas e o humor oswaldiano, não percebida inteiramente em 1945, as soluções ainda são enfocadas como elaboração formal específica do campo literário. Os termos da avaliação dizem respeito ao domínio narrativo, de técnicas e de composição geral, em relação ora com as tendências anarquistas profundas da personalidade literária do autor, ora com a intenção ideológica de fazer romance social. Sucesso e insucesso vão depender de combinações possíveis dessas variáveis.

No ensaio de 1945, Estouro e libertação, está no horizonte do crítico a realização esteticamente amadurecida de crítica social. $O$ resultado esperado, como superação do passadismo e da "crítica puramente negativa", era uma "perspectiva sintética de crítica social construtiva". O modelo de 
pensamento aqui é, como se percebe facilmente, a dialética hegeliana, nos seus três momentos: tese, antítese, síntese. A solução estética devia ajustar os restos de esteticismo danunzianos, possivelmente eliminando-os, forjar um estilo tão vivo quanto o das Memórias sentimentais, embora não necessariamente o mesmo, e aprofundar a psicologia das personagens, de certa maneira domando a mobilidade vertiginosa do Serafim. Dessas providências literárias parece depender a eficácia da "crítica social", que é a intenção declarada do autor e a perspectiva sintética visada pelo crítico. Salvo engano, pressupõe-se nesse ensaio uma relação dada, resolvida em si mesma, entre a intenção de crítica social e a elaboração literária bemsucedida, em termos de composição, psicologia das personagens, técnicas narrativas.

Em 1970, o momento negativo da sátira é considerado o mais alto na trajetória do escritor, como vimos antes. Em termos especificamente literários, esta já era a opinião de Antonio Candido em 1945. Enfatizam-se, na Digressão sentimental sobre Oswald de Andrade, as conquistas formais ligadas à descontinuidade, mobilidade e simultaneidade na narrativa, e conferem-se outros valores aos traços sumários da sátira e à falta de encaminhamento narrativo sintético do estilo sincopado, que em 1945 pareciam dificultar a aceitação do Par, sobretudo do Serafim, como momento definitivo.

Nas análises de romances empreendidas nos anos 70, das Memórias de sargento de milícias e d'o cortiço, os recursos e técnicas não são tratados com a mesma autonomia, mas sempre adquirem sentido e valor junto a outros elementos da narrativa, às modificações condicionadas pela matéria local, às ideologias, recuperando-se a autonomia da forma na chave de uma historicidade profunda, que a distancia até das intenções declaradas dos autores.

O ensaio de Roberto Schwarz sobre a poesia Pau-Brasil, publicado em 1987, tem Antonio Candido muito presente: leva em consideração a valorização formal vanguardista dos ensaios sobre Oswald e os pressupostos de análise dialética desenvolvidos pelo crítico. Dando mais peso a estes últimos, empreende um exame da poesia oswaldiana por um viés não tentado, mas de certa forma pressuposto pelo mestre, como vimos anteriormente.

Em relação às inovações formais, Schwarz considera que "o uso inventivo e distanciado das formas parece colocar a poesia de Oswald no campo inequivocamente crítico. E de fato, sempre que o alvo é alguma espécie de rigidez oficialista, a quebra da convenção tem este efeito" (SCHWARZ, 1987, p. 25). Passando para a configuração ideológica da poesia, mostra que as técnicas de nivelamento de elementos heterogêneos, muito apuradas em termos formais, não funcionam criticamente, pelo contrário. $O$ 
humor, o ar de piada, é que, no final, recupera criticamente a poesia oswaldiana. Antonio Candido, sem fazer as correlações propostas por Schwarz, também já indicara que o melhor da obra de Oswald passava pelo sarcasmo.

\section{Rupturas E CONTINUIDADES Do PRIMEIRo MODERnismo}

No ensaio Literatura e cultura de 1900 a 1945 , Antonio Candido explica as relações do Modernismo com o período anterior. Em outros panoramas, não dará mais a mesma atenção ao assunto. "Comparada com a da fase seguinte (1922-1945) a literatura aparece aí essencialmente como literatura de permanência. Conserva e elabora os traços desenvolvidos depois do Romantismo, sem dar origem a desenvolvimentos novos". O romance mais típico do período, segundo Candido, "forma-se pela confluência do que há de mais superficial em Machado de Assis, da ironia amena de Anatole France e dos romances franceses do pós-naturalismo, sentenciosos, repassados de sexualismo frívolo: Paul Bourget, Abel Hermant" (CANDIDo, 2000, p. 113). Além desse tipo de narrativa, Antonio Candido aponta a grande voga do conto sertanejo, "gênero artificial e pretensioso", também um tipo de permanência decadente do regionalismo romântico.

$\mathrm{Na}$ poesia, teria havido algo muito semelhante, com a observação de que o Naturalismo na prosa havia sido muito mais vigoroso que o Parnasianismo na poesia, apesar do grande talento de seus representantes. Este último contribuíra de maneira pouco essencial para a poesia brasileira, pois se lhe havia conferido maior "regularidade plástica", ter-lhe-ia também reforçado o pendor retórico. O Simbolismo, mais original, estava restrito às obras de dois autores, Cruz e Sousa e Alphonsus de Guimaraens, pouco conhecidos na época, e congregava manifestações espiritualistas.

Estas últimas são reconhecidas pelo crítico como proposta de renovação anterior ao Modernismo, articulada a partir da Primeira Guerra Mundial, em torno da filosofia de Farias Brito, da crítica de Nestor Victor e, depois, do "apostolado intelectual de Jackson de Figueiredo", contando com a influência dos simbolistas belgas e de Antônio Nobre. Entretanto, Antonio Candido julga que o movimento espiritualista não consegue concretizar de fato uma renovação porque não se separa da tradição, constituindo apenas mais uma face da literatura de permanência. O Modernismo, muito mais radical, acabou sobrepondo-se a ele.

A posição do primeiro Modernismo em relação às duas tendências, a do academismo dominante e a dos espiritualistas, é de ruptura, embora 
assuma atitude mais radical diante da primeira, a quem combate muitas vezes ao lado da última. Entretanto, retoma de ambos alguns temas e atitudes pouco aprofundados neles, como "a pesquisa lírica tanto no plano dos temas quanto dos meios formais; a indagação sobre o destino do homem e, sobretudo, do homem brasileiro; a busca de uma forte convicção." (CANDIDO, 2000, p. 119) Esta retomada, por sua vez, dada a brusca mudança de plano em que se dá, pode ser encarada também como ruptura.

Em termos gerais, portanto, em relação ao período anterior, o Modernismo rompe com a literatura de permanência, incluindo aqui o conto sertanejo, e com um movimento de renovação em curso ainda excessivamente tradicionalista, retomando alguns de seus temas, porém para subvertê-los.

A ênfase na ideia de ruptura modernista e a consideração praticamente em bloco do movimento têm gerado nos últimos anos alguns questionamentos por parte dos que estudam autores pertencentes ao chamado Pré-Modernismo. Esses questionamentos, é bom lembrar, não se dirigem especificamente a Antonio Candido, mas aos que vêm trabalhando com essa configuração de períodos, ou seja, a maior parte da crítica literária brasileira.

Alfredo Bosi, no início do tópico sobre o Modernismo do seu mais conhecido livro de historiografia, lembra o que viria a se constituir mais tarde um ponto de discussão na crítica literária brasileira: nem todos os modernistas eram modernos e nem todos os modernos eram modernistas. Ou seja, havia autores, que embora não tivessem participado do movimento modernista, e atuassem antes dele, faziam uma literatura mais reconhecidamente moderna, do ponto de vista de hoje, do que outros nele engajados (BOSI, 1994, p. 375). Não que Alfredo Bosi desejasse com isso questionar o marco de renovação que foi o movimento modernista, pelo contrário, mas essa diferenciação ou confusão entre moderno e modernista, nos últimos tempos, de fato vem tendendo a tornar menos nítida a fronteira de renovação da literatura brasileira, que Antonio Candido nos panoramas demarca muito claramente a partir da Semana de Arte Moderna.

o fato de o crítico apontar um evento específico como marco e não a obra de um autor, como faz com Machado de Assis, na Formação da Literatura Brasileira, indica o interesse de valorizar a intervenção coletiva, que atua sobre padrões literários mas também sociais.

As possibilidades de renovação da literatura brasileira, no início do século XX, são tratadas do ponto de vista de movimentos coletivos com atuação diversificada na vida intelectual. Por isso, os espiritualistas e simbolistas, que tiveram uma atuação conjunta em várias áreas do saber, mereceram figurar no ensaio Literatura e cultura de 1900 a 1945 como tentativa de renovação anterior ao Modernismo, com permanências 
significativas nos anos 30 e em tensão com o engajamento social da década ${ }^{2}$.

A renovação modernista importa sobretudo, nos panoramas, como repercussão coletiva. Numa entrevista, o repórter pergunta a Antonio Candido se teria sido Mário ou Oswald de Andrade quem mais teria contribuído para esta renovação. Ele trata logo de colocar a questão em outros termos. A nenhum dos dois, individualmente, poder-se-ia atribuir essa conquista. "O divisor de águas foi o movimento modernista, coletivo, de que fizeram parte e se exprime simbolicamente pela data de 1922. Eles foram protagonistas" (CANDIDO, 1992a, p. 243).

Por isso, haver um autor já moderno antes do movimento ou um modernista menos moderno, isoladamente, não muda o fato de que os esforços reunidos da década de 20 lograram alterar padrões de gosto e critérios críticos, sobrepondo-se a valores tradicionalmente aceitos. As batalhas travadas em 20 prepararam o momento de tranquilidade para a produção dos autores de 30.

Em relação ao Modernismo da década de 30, o esforço do crítico será no sentido de estabelecer uma linha de continuidade. A década de 30 será vista como momento de consolidação das propostas dos anos 20.

No ensaio A revolução de 1930 e a cultura, Antonio Candido vincula todas as conquistas de 30 ao movimento de 20 , chamando a este período de uma grande sementeira. Aquelas conquistas seriam, sobretudo, "atualizações" (no sentido da passagem da potência ao ato) do que se esboçara nos anos 20 (enfraquecimento da literatura acadêmica, aceitação consciente ou inconsciente das inovações formais e temáticas, alargamento das "literaturas regionais" à escala nacional, polarização ideológica). Na década seguinte, o movimento se rotiniza, o excepcional torna-se normal, mais aceito, menos contundente. $\mathrm{O}$ anticonvencionalismo é visto como direito, não mais como transgressão e os escritores de 30 beneficiam-se da liberdade conquistada (CANDIDO, 1989b, p. 186).

O mesmo ensaio utiliza a divisão proposta por Lafetá entre projeto estético (década de 20) e projeto ideológico (década de 30) para apontar uma

${ }^{2}$ Antonio Candido detém-se pouco em manifestações individuais de renovação. $O S$ sertões, de Euclides da Cunha, por exemplo, teriam inclusive favorecido a voga do conto sertanejo, antes que os modernistas compreendessem e redirecionassem o que havia de correto em sua inserção na realidade do país. Poetas como Augusto dos Anjos e Alphonsus de Guimaraens e escritores como Euclides e Lima Barreto, embora oferecessem opções divergentes no período, não conseguiram afirmar-se pelo que tinham de renovador. O crítico não nega, assim, a existência de tendências novas anteriores ao Modernismo, mas a incapacidade destas de renovar para além da obra individual, de romper com padrões mais amplos. No caso de Lima Barreto, que tinha um programa de renovação literária e militou publicamente por ele, os motivos dessa incapacidade merecem reflexão. 
perda de 30 em relação a 20 , que seria a menor consciência da elaboração formal na prosa, com poucas exceções, devido à obsessão no tratamento dos "problemas", tanto por parte dos escritores "sociais", quanto dos espiritualistas. Tal atitude "conduzia ao espontâneo, que no limite é o informe" (CANDIDO, 1989b, p. 197). A poesia teria seguido outro caminho, prolongando uma experiência poética que começara nos anos 20.

Noutro ensaio, vindo a público originalmente como comunicação em um encontro sobre literatura em Washington, um ano antes, a avaliação é feita de ângulo diferente e procura mostrar a importância da conquista estilística do romance de 30 , ainda que não inteiramente consciente:

Os decênios de 30 e 40 foram momentos de renovação dos assuntos e busca da naturalidade, e a maioria dos escritores não sentia plenamente a importância da renovação estilística que por vezes efetuavam. Mas não nos esqueçamos que esses autores (quase todos despreocupados em refletir sobre a linguagem literária) estavam de fato construindo uma nova maneira de escrever, tornada possível pela liberdade que os modernistas do decênio de 1920 haviam conquistado e praticado (CANDIDO, 1989a, p. 205).

Os problemas literários, quando se pensa estilo, forma e tema dissociadamente, são tão espinhosos que Antonio Candido no mesmo ensaio, analisando a literatura da década de 70 , encontra novamente um impasse dado nos mesmo termos deste último, mas que avalia de maneira diferente. Em presença da ficção vanguardista dos anos 70 , renovadora, altamente consciente dos recursos formais e jogando com eles, vai considerar "mais bem realizadas e satisfatórias algumas que foram elaboradas sem preocupação de inovar, sem vinco de escola, sem compromisso com a moda; inclusive uma que não é ficcional" (CANDIDO, 1989a, p. 215).

Esses impasses, formulados por Antonio Candido em dois panoramas, em curto espaço de tempo, mostram a grande mobilidade do crítico, capaz de afirmar o critério de valor da elaboração formal consciente, reconhecer a revolução estilística da "desliterarização" da literatura brasileira e sobrepor a obras resultantes de elaborada pesquisa formal outras de escrita mais tradicional. São três momentos diferentes, em que se trata ora de afirmar um valor, ora de tratar as conquistas de um período literário, ora de comparar a qualidade das obras sem submetê-las a um valor prévio.

Na citação acima, também é digna de nota a ênfase na organicidade entre o Modernismo de 20 e o de 30 , referida mais acima. A nova maneira de escrever foi "tornada possível" pela liberdade conquistada em 20. Autores importantes como Graciliano Ramos e Dionélio Machado, cujas formas de escrever não haviam sofrido influência direta do primeiro Modernismo, ligavam-se a ele por terem se beneficiado da liberdade anteriormente 
conquistada. $\mathrm{O}$ argumento não é meramente retórico, mas fica a pergunta sobre quais seriam, pois, os antecedentes e desdobramentos da prosa modernista.

\title{
5 A Título de Conclusão
}

É preciso lembrar que as ideias discutidas nesse trabalho vieram em grande parte de panoramas, muitas vezes preparados para exposição oral em eventos. É o que Antonio Candido mesmo chamou de "crítica esquemática". De qualquer forma, creio que não é descabido concluir que o grande mestre da crítica brasileira optou, na tarefa de explicar e sistematizar o Modernismo brasileiro, por uma lógica centrípeta, privilegiando elos e linhas eficazes de renovação da literatura brasileira.

\section{RESUMO}

Este ensaio pretende reunir, apresentar e discutir alguns aspectos da renovação da literatura brasileira empreendida pelo Modernismo na primeira fase, apontados na obra ensaística de Antonio Candido. Com isso, procura entender a importância das conquistas, os critérios e valores implicados, bem como as formas de sistematização do movimento propostas pelo crítico. Palavras-chave: modernismo; Antonio Candido; sistema literário.

\begin{abstract}
This essay intends to gather, present and discuss some aspects of the renewal of Brazilian literature undertaken by the first Modernism, indicated in the literary criticism of Antonio Candido. In this way, it seeks to understand the importance of achievements, criteria and values involved, as well as the ways to systematize the movement proposed by the critic.

Key-words: modernism; Antonio Candido; literary system.
\end{abstract}

\section{REFERÊNCIAS}


BOSI, Alfredo. História concisa da Literatura Brasileira. 3. ed. São Paulo: Cultrix, 1994.

CANDIDO, Antonio. "A nova narrativa". In: A educação pela noite e outros ensaios. 2. ed. São Paulo: Ática, 1989a. p. 199-215.

. "A revolução de 1930 e a cultura". In: A educação pela noite e outros ensaios. 2. ed. São Paulo: Ática, 1989b. p. 181-198.

. "Digressão sentimental sobre Oswald de Andrade". In: Vários escritos. 4. ed. São Paulo: Duas Cidades; Rio de Janeiro: Ouro sobre Azul, 2004. p. 33-61.

. "Entrevista". In: Brigada Ligeira e outros escritos. São Paulo: Editora da Unesp, 1992a. p. 229-246.

. "Estouro e libertação". In: Brigada ligeira e outros escritos. São Paulo: Editora da Unesp, 1992b. p. 17-32.

. Formação da Literatura Brasileira: momentos decisivos. 7. ed. Belo Horizonte/Rio de Janeiro: Itatiaia, 1993.

. "Literatura e cultura de 1900 a 1945: panorama para estrangeiros". In: Literatura e sociedade. 8. ed. São Paulo: T. A. Queiroz Editor, 2000. p. 109-138.

. "Plataforma da nova geração". In: Textos de intervenção. Seleção, apresentação e notas de: Vinícius Dantas. São Paulo: Duas Cidades; Editora 34, 2002a. p. 237-250.

. "Variações sobre temas da Formação". In: Textos de intervenção. Seleção, apresentação e notas de: Vinícius Dantas. São Paulo: Duas Cidades; Editora 34, 2002b. p. 93-120.

SCHWARZ, Roberto. "A carroça, o bonde e o poeta modernista". In: Que horas são? Ensaios. São Paulo: Companhia das Letras, 1987. p. 11-28.

. Duas meninas. São Paulo: Companhia das Letras, 1997.

Submetido em: 20/03/2008.

Aceito em: 25/11/2008. 